\title{
Nitrogen nutrition of rice plants measured by growth and nutrient content in pot experiments. 4. Role of the water regime
}

\author{
W. Dijkshoorn and M. Ismunadji ${ }^{1}$
}

Institute for Biological and Chemical Research on Field Crops and Herbage, Wageningen, the Netherlands

Accepted: 9 January 1972

\section{Summary}

Available nitrogen in a flooded soil under rice was assessed by measuring the $\mathrm{N}$ the plants could extract from the soil.

During flooding the supply of ammonium was not changed, while nitrate rapidly denitrified.

Applied to the dry soil ammonium nitrified. When later the soil was flooded for wet rice growing, nitrate denitrified and the supply of $\mathrm{N}$ was roughly halved.

A change in soil $\mathrm{pH}$ in an acid direction to $\mathrm{pH} 4.5$ was sufficient to check nitrification and loss of $\mathrm{N}$ at pre-flood application of ammonium.

\section{Introduction}

A natural supply of available $\mathrm{N}$ is the conversion of organic soil- $\mathrm{N}$ into ammonia which adds a proton (donated by the soil or by some acid generated by the process) to yield ammonium. The process, called ammonification, raises the concentration of ammonium in the soil at the expense of the stock of organic $\mathrm{N}$. The reduction of $\mathrm{N}$ is unchanged, and ammonification continues when the soil is inundated. Unfertilized soil under rice for a long time and inundated after a period of drainage gained in ammonium by about $1 \mathrm{meq} / \mathrm{kg}$ soil (Bhuiyan, 1949). $\mathrm{N}$ removed by the plants was not taken into account, so that probably more $\mathrm{N}$ ammonified.

Nitrification converts ammonium into nitrate. The oxidation stage of $\mathrm{N}$ is raised, the process requires a free access of oxygen and stops when the soil is inundated.

If ammonium is added as the salt of a strong mineral acid, 2 equivalents of acid are generated per ion equivalent of ammonium converted to nitrate:

$\mathrm{NH}_{4} \mathrm{Cl}+4 \mathrm{O} \rightarrow \mathrm{HNO}_{3}+\mathrm{HCl}+\mathrm{H}_{2} \mathrm{O}$

Since acid is produced, nitrification is likely to proceed faster in more alkaline soils. Incubation experiments showed that a $\mathrm{pH}$ higher than 5 was obligatory if detectable rates of nitrification were to be maintained (van Tuil and Lampe, 1964).

Denitrification is the reduction of nitrate in the soil to gaseous nitrogen or nitrous oxide. The equation:

${ }^{1}$ Present address: Central Research Institute for Agriculture, Bogor, Indonesia. 


\section{$2 \mathrm{KNO}_{3}+10 \mathrm{H} \rightarrow \mathrm{N}_{2}+4 \mathrm{H}_{2} \mathrm{O}+2 \mathrm{KOH}$}

shows that the $\mathrm{N}$ is lost to the atmosphere, and that the nitrates of metal cations are replaced by alkali which can neutralize soil acidity. Although it would follow that nitrate denitrifies more rapidly in acid soils, it has been reported that here, nitrite may accumulate and kill denitrifying organisms (Jansson and Clark, 1952). At moderate acidity of pH 4.9, Wyler and Delwiche (1954) observed a loss of $70 \%$ by denitrification. From this it seems that nitrate may still denitrify at $\mathrm{pH}$ values low enough to stop nitrification.

The oxidation stage of $\mathrm{N}$ is lowered and denitrification is an anaerobic process. If the soil is waterlogged, denitrification is enormously stimulated and serious losses of $\mathrm{N}$ may occur by its release to the atmosphere.

These modifications of soil $\mathbf{N}$ due to the activity of micro-organisms are often involved in relating the water regime with the $\mathrm{N}$ supply characteristics of wet soils under rice (Ponnamperuma, 1964). In a flooded soil ammonium is stable for a long time. Ammonium applied during drainage nitrifies, and the resulting nitrate denitrifies when later the soil is inundated for rice growing so that shortage of $\mathbf{N}$ may develop. If nitrification is checked, ammonium supplied during drought will have the same effectiveness as when directly applied to the flooded soil in wet rice growing.

The present work demonstrates the effect of nitrification, denitrification, soil $\mathrm{pH}$ and water regime on the availability of $\mathrm{N}$ from ammonium and nitrate fertilizer. Uptake by rice plants grown to a yield level at which $\mathrm{N}$ was limiting, was considered closely to approximate the amount the soil could supply.

\section{Experimental}

Pots closed at the bottom were filled with $7 \mathrm{~kg}$ of a sandy garden soil (5\% organic matter; pH-water 5.5) with either $40 \mathrm{meq}$ ammonium sulphate, or $40 \mathrm{meq}$ calcium nitrate in sufficient water to bring soil moisture to about $60 \%$ saturation. In addition the water contained $20 \mathrm{meq}$ potassium sulphate, and either $100 \mathrm{meq}$ sulphuric acid resulting in $\mathrm{pH}$ 4.5, or no acid (pH 5.5), or 3000 meq suspended calcium carbonate resulting in pH 7.5.

In this way, $\mathrm{N}$ was added either as ammonium or as nitrate, and $\mathrm{pH}$ was varied within a range within which the rate of nitrification could fall in an acid direction from high to practically zero.

Two water levels were superimposed on day 0 of dressing.

One half of the pots was immediately inundated, the other half was kept dry.

During the first 38 days denitrification in the wet soil or nitrification in the dry soil was allowed to proceed without plants.

On day 38 the pots were planted with 4 small rice seedlings, and all were flooded throughout the growing period to study to what extent plant uptake and denitrification exhausted soil $\mathrm{N}$.

Flooded means maintaining a $3-\mathrm{cm}$ water layer above the soil throughout the experiment.

Dry refers to a 38-day period of maintaining $60 \%$ water saturation followed by planting and inundation.

The experiment was made in a greenhouse thermostated between 25 and $30^{\circ} \mathrm{C}$. On day 84 , when there was definite evidence of $\mathrm{N}$ shortage judged from plant size and leaf colour, the tops of the plants were cut at a height of $7 \mathrm{~cm}$ above the soil, dried, weighed, powdered and analysed for $\mathbf{N}$. 


\section{Results and discussion}

Earlier work showed that in sufficient supply the amount of $\mathrm{N}$ absorbed was controlled by plant size. At first concentration of $\mathrm{N}$ in the plant tops was $2.5 \mathrm{meq} / \mathrm{g} \mathrm{DM}$, independent of growth duration and form of $\mathrm{N}$. It was not until the yield had risen above the level of $20 \mathrm{~g} \mathrm{DM} /$ pot that self shading began to affect the utilization of nitrate and lowered the concentration of the plants on nitrate medium (Dijkshoorn and Ismunadji, 1972b).

Two-thirds of the absorbed $\mathrm{N}$ was stored by the tops. Algae growing on the inundated soil took up about one-fourth of the $\mathrm{N}$ supplied.

Thus the plants, grown to depletion, had consumed three-fourths and translocated half of the $\mathrm{N}$ the medium could supply to the tops (Ismunadji and Dijkshoorn, 1971; Dijkshoorn and Ismunadji, 1972a).

$\mathrm{N}$ stored by the tops was then fixed, and any further growth continuing into depletion caused a decrease in the concentration of $\mathrm{N}$ in the dried tops.

A way of assessing the $\mathrm{N}$ a given soil can supply is growing rice on it until the yield has risen above the depletion level. This can be roughly estimated from plant size and leaf colour, and should be confirmed by $\mathrm{N}$ concentrations lower than $2.5 \mathrm{meq} / \mathrm{g}$ in dried tops.

Yield times concentration gives meq $\mathrm{N}$ in the tops per pot.

Fig. 1 shows $\mathrm{N}$ and $\mathrm{DM}$ for the various treatments. The interrupted straight line through the origin slopes at $2.5 \mathrm{meq} / \mathrm{g}$ DM. It is the assumed result, if there had been excess of $\mathrm{N}$ and for either form of $\mathrm{N}$, because the highest yield was only little over $20 \mathrm{~g} \mathrm{DM} /$ pot.

The plotted points lie at the right of this line. Their positions indicate that $\mathbf{N}$ in the supply was limiting uptake. Hence, each ordinate measured one-half of the $\mathbf{N}$ the soil could supply for use by plants and algae.

Fig la is for $40 \mathrm{meq}$ ammonium supplied to the inundated soil. The difference in uptake. from the dressed soil (squares) between the three $\mathrm{pH}$ values is of a degree $(10 \%)$ that one would normally associate with experimental errors in this type of experiments. Roughly averaged, the tops stored $30 \mathrm{meq} \mathrm{N}$.

The circle is for plants grown in the soil of $\mathrm{pH} 5.5$ without any addition which translocated $11 \mathrm{meq} N$ into the tops. Since uptake by tops from the dressed soil was roughly $20 \mathrm{meq}$ greater, the supply of $40 \mathrm{meq}$ ammonium remained available for use by plants (and algae). Volatilization of ammonia was hardly expected, the highest pH being 7.5, and $\mathrm{pH}$ of the acid/base couple ammonium/ammonia being about 9 .

At $\mathrm{pH} 4.5$ the yield was low and $\mathrm{N}$ in the tops concentrated to $2.1 \mathrm{meq} / \mathrm{g} \mathrm{DM}$. At $\mathrm{pH}$ 5.5 and 7.5 with the better yields $\mathrm{N}$ was diluted to about $1.5 \mathrm{meq} / \mathrm{g} \mathrm{DM}$, but uptake remained constant at 30 meq $\mathrm{N}$, because the soil had no more $\mathrm{N}$ to further coordinate uptake with growth.

Fig. 1b shows that nearly all the nitrate supplied to the flooded soil denitrified during the first 38 days before planting, because the plants grown in these pots eventually absorbed only little more $\mathrm{N}$ than those in the continously flooded unfertilized soil.

In Fig. 1c the results are of ammonium supplied to the dry soil. At pH 5.5 and 7.5 ammonium nitrified, and the resulting nitrate commenced to denitrify, when on day 38 the soil was flooded and planted. With the increase in uptake by the growing plants the supply was reduced by denitrification to such a point that the plants eventually translocated only 20 and 15 meq $N$ to the tops, respectively.

The dry soil dressed with ammonium at $\mathrm{pH} 4.5$ supplied $30 \mathrm{meq} \mathrm{N}$ to the tops. Apparently, ammonium refused to nitrify at this low $\mathrm{pH}$, because $\mathrm{pH}$ in itself had no detectable inhibitive effect on denitrification (compare Fig. 1b). Since nitrification was blocked at pH 4.5, the increase in uptake due to fertilizer was more closely approximated by subtracting the 

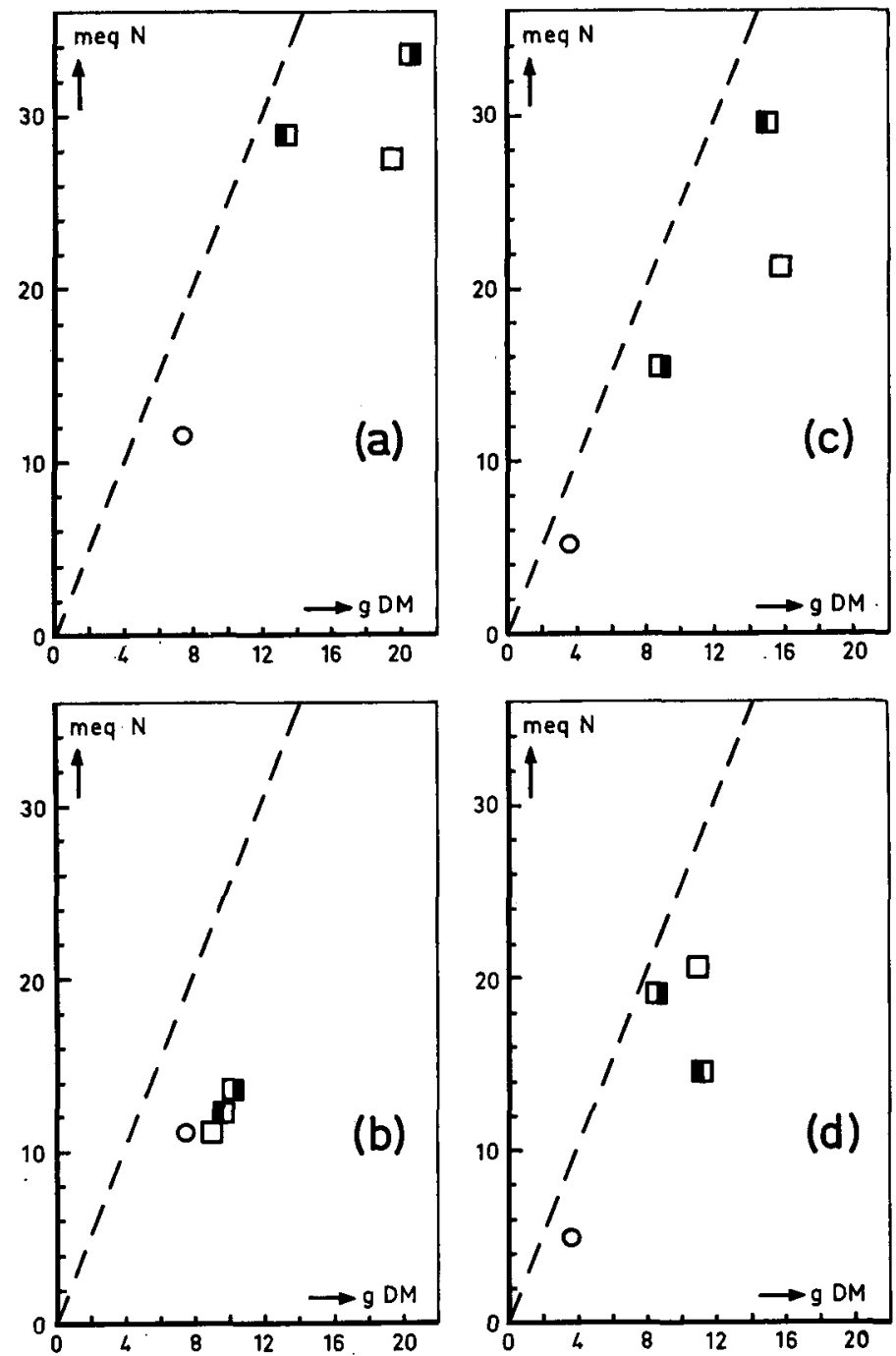

Fig. 1. Yield of $N$ in meq and DM in g per pot on day 84 in harvesting the tops of the plants. Squares relate to the fertilized soil. Plots with the left half black relate to soil $\mathrm{pH} 4.5$, those with the right half black to soil pH 7.7. All open plots are for soil $\mathrm{pH} 5.5$. The circles relate to plants that grew in the natural, unfertilized soil. The interrupted straight line is for $2.5 \mathrm{meq} \mathrm{N} / \mathrm{g} \mathrm{DM}$. a. ammonium supplied to the flooded soil; b. nitrate supplied to the flooded soil; c. ammonium supplied to the dry soil; d. nitrate supplied to the dry soil.

control value of Fig. 1a, where nitrification was also checked, in this case by waterlogging. The difference of $20 \mathrm{meq} N /$ pot then indicated that there was no loss of $N$. The survival of ammonium during previous drought made it completely available for use by the plants during inundation. 
Fig. 1d refers to nitrate supplied during drought. It was not until the soil was flooded and planted that denitrification commenced. Before all the nitrate denitrified, the plants obsorbed nitrate and eventually translocated about $20 \mathrm{meq} N$ to the tops from the dressed soil.

The unfertilized soil gave off only $5 \mathrm{meq} \mathrm{N}$ presumably because it contained ammonium which nitrified during previous drought, so that the soil lost half its $\mathrm{N}$ by denitrification during wet rice growing.

Some indication of reconstructing the trend in available soil $\mathrm{N}$ may be obtained from the earlier work on the characteristics of growth and utilization of $\mathrm{N}$.

During growth the dry weight increased exponentially by doubling in 6 days (Ismunadji and Dijkshoorn, 1971). In sufficient supply, uptake of $\mathrm{N}$ bore a constant relation to the dry weight with $2.5 \mathrm{meq} \mathrm{N} / \mathrm{g} \mathrm{DM}$. In this case, the highest yield attained, of $20 \mathrm{~g} \mathrm{DM}$, would correspond to $50 \mathrm{meq} \mathrm{N}$, and each of these substances would have risen to its ultimate level in proportion to the other.

With this in mind, the solid ascending curve, convex in respect of the base in Fig. 2, would represent the trend in uptake with time, if no exhaustion had occurred. Any difference in growth due to form of $\mathrm{N}$ in the supply may be considered of little importance, because the plants were mainly relying upon ammonium which was the stable form in the inundated soil on which they grew.

Fast-growing cultural plants do not economize on $\mathrm{N}$ in limited supply by reducing tissue concentration of $\mathbf{N}$ with the progressive decrease in soil concentration resulting from uptake. The transition from sufflcient supply to no supply is not a gradual process, if measured in intervals of days, but occurs suddenly when available $\mathrm{N}$ drops to nothing in the medium.

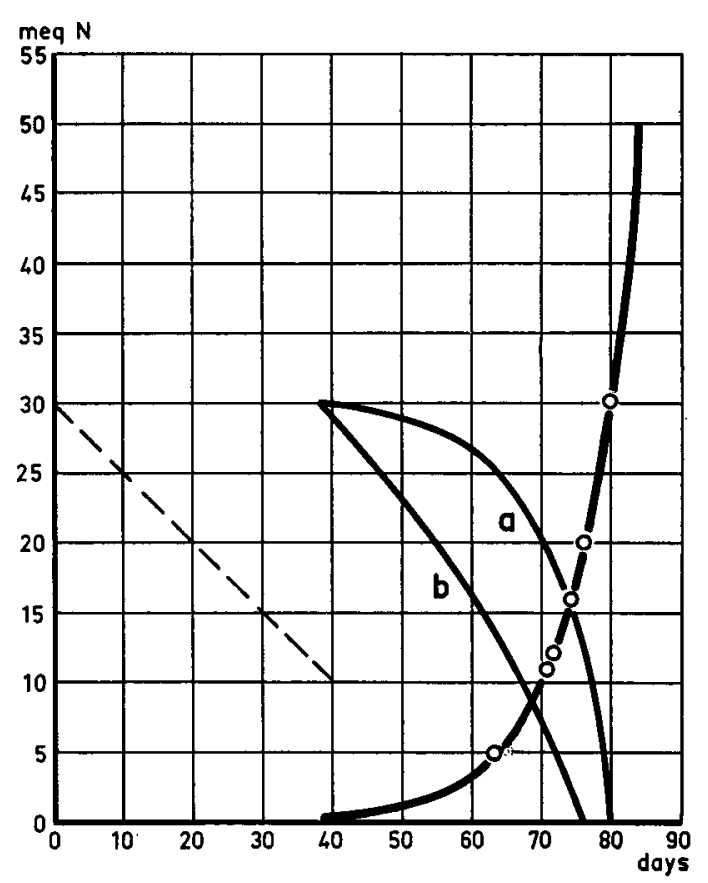

Fig. 2. Time course of $\mathrm{N}$ in meq/pot. The solid ascending curve is for exponential $\mathbf{N}$ uptake at $2.5 \mathrm{meq} \mathrm{N} / \mathrm{g}$ DM and the weight of DM doubled in 6 days, presumably representing uptake by tops at adequate supply. Circles on the line are observed udtakes. Dashed line: $\mathrm{N}$ loss from soil by denitrification in the flooded soil Curve a: $\mathrm{N}$ loss from soil by uptake; curve b: $\mathrm{N}$ loss from soil by uptake and denitrification.

Data based on $\mathrm{N}$ in tops of plants. For all the $\mathbf{N}$ the ordinates should be multiplied by two. 
A rough figure for the time of exhaustion may therefore be obtained by marking the observed uptakes on the uptake curve for continuous supply in Fig. 2, and reading the corresponding times on the horizontal axis.

For instance, the unfertilized continuously flooded soil supplied $11 \mathrm{meq} N$ to the tops and was exhausted on day 71. If dry for the first 38 days, it supplied 5 meq $N$ to the tops and was exhausted on day 63 . The flooded soil dressed with ammonium sustained $\mathrm{N}$ uptake until $30 \mathrm{meq} \mathrm{N}$ had been translocated to the tops on day 80. Ammonium supplied to the dry soil at $\mathrm{pH} 7.5$ led to exhaustion on day 74 when the plants had translocated 16 meq $\mathrm{N}$ to the tops, and so on.

The rate of denitrification of nitrate in the flooded soil is the slope of the interrupted line drawn from $30 \mathrm{meq} N$ on day $O$ of its application to $11 \mathrm{meq} N$ (the yield of the unfertilized, continuously inundated soil) on day 38 of planting. That denitrification had decomposed most, but not all of the nitrate on day 38 was concluded from the small excess in $\mathbf{N}$ uptake over the control by the plants grown on the continuously inundated nitrate soil (compare Fig. 1b).

The slope of the line indicates that nitrate- $\mathrm{N}$ was lost at a rate of $0.5 \mathrm{meq} / \mathrm{day}$, but the linear character of the decrease in available $\mathrm{N}$ by denitrification is of course a matter of doubt.

Direct flooding and $\mathrm{pH} 4.5$ both intervened as checks on nitrification. Therefore, ammonium supplied to the flooded soil at all $\mathrm{pH}$ values and to the dry soil at $\mathrm{pH} 4.5$ caused no change in soil $\mathrm{N}$ other than its uptake for use by the growing plants and algae. The curve representing available $\mathrm{N}$ in the soil against time mirrors the uptake curve for continuous supply from day 38 onwards and drops to zero on day 80 , when the plants had translocated $30 \mathrm{meq} \mathbf{N}$ to the tops, and had completely exhausted the soil (curve a).

Nitrate supplied to the dry soil remained unchanged until on day 38 the soil was fllooded and planted. From then on exhaustion of the soil was the additive effect of denitrification $(0.5 \mathrm{meq} / \mathrm{day})$ and uptake by the plants, and could be represented by the additive curve $b$, dropping more abruptly from 30 meq $\mathrm{N}$ on day 38 to nothing on day 76 , meanwhile permitting the plants to translocate $20 \mathrm{meq} \mathbf{N}$ from the soil to the tops.

It must be noted that with nitrate at soil pH 4.5 the tops contained $15 \mathrm{meq} \mathrm{N}$ (compare Fig. 1d) and depletion came a few days earlier. This would be in conformity with the idea that denitrification is more rapid when the soil is more acid.

In the dry soil at pH 5.5 sufficient ammonium nitrified to cause early exhaustion. Depletion came on day 76 when 20 meq $\mathrm{N}$ had been moved to the tops. The trend in depletion with time by uptake and denitrification was the same as for nitrate supplied to the dry soil (curve $\mathrm{b}$ in Fig. 2). Here too, half of the fertilizer $\mathrm{N}$ was decomposed by denitrification when the other half was obserbed for use by the plants.

At pH 7.5 nitrification was certainly accomplished more quickly. But this could not be directly related to the low yield of only $16 \mathrm{meq} N$ (Fig. 1c), because the same water regime with nitrate in place of ammonium yielded $19 \mathrm{meq} \mathrm{N}$ in the tops (Fig. 1d). In so far as tested, this may indicate that more intense nitrification during drought indirectly assisted denitrification through more rapidly attaining anaerobiosis at subsequent flooding for wet rice growing. The complete conversion of $40 \mathrm{meq}$ ammonium into nitrate would require the oxygen of 8 litres of air.

All the data refer to $\mathrm{N}$ in the tops of the plants. The assumption was made that the results of Fig. 2 were valid for the whole system of plants, algae and soil, if the ordinates were multiplied by two, and this was supported by evidence obtained earlier. The unattractive feature of whole plant and alga analysis was a marked and varying contamination of roots and algae, resulting in inhomogeneous sampling. 


\section{References}

Bhuiyan, S., 1949. Transformation of nitrogen in rice soil. Soil Sci. 67: 231-237.

Dijkshoorn, W. \& M. Ismunadji, 1972a. Nitrogen nutrition of rice plants measured by growth and nutrient content in pot experiments. 2. Uptake of ammonium and nitrate from a waterlogged soil. Neth. J. agric. Sci. 20: 44-57.

Dijkshoorn, W. \& M. Ismunadji, 1972b. Nitrogen nutrition of rice plants measured by growth and nutrient content in pot experiments. 3. Changes during growth. Neth. J. agric. Sci. 20:133-144.

Ismunadji, M. \& W. Dijkshoorn, 1971. Nitrogen nutrition of rice plants measured by growth and nutrient content in pot experiments. 1. Ionic balance and selective uptake. Neth. J. agric. Sci. 19: 223-236.

Jansson, S. L. \& F. E. Clark, 1952. Losses of nitrogen during decomposition of plant material in the presence of inorganic nitrogen. Proc. Soil Sci. Soc. Am. 16: 330-334.

Ponnamperuma, F. N., 1964. Dynamic aspects of flooded soils and the nutrition of the rice plant. In: The mineral nutrition of the rice plant. Symp. Int. Rice Res. Inst. (Baltimore 1964): 295328.

Tuil, H. D. W. van \& J. E. M. Lampe, 1964. Control of nitrification by 2-chloro-6-(trichloromethyl) pyridine. Jaarb. Inst. biol. scheik. Onderz. LandbGewass. 1964: 161-163.

Wyler, J. \& C. C. Delwiche, 1954. Investigations on the denitrifying process in soil. Pl. Soil 5: 155169. 